Invertebrate Biology 129(1): 1-16.

(C) 2010, The Authors

Journal compilation (C) 2010, The American Microscopical Society, Inc.

DOI: $10.1111 / \mathrm{j} .1744-7410.2010 .00193 . \mathrm{x}$

\title{
Evolutionary emergence of synaptic nervous systems: what can we learn from the non-synaptic, nerveless Porifera?
}

\author{
Michael Nickel ${ }^{\mathrm{a}}$ \\ Institut für Spezielle Zoologie und Evolutionsbiologie mit Phylogenetischem Museum, \\ Friedrich Schiller University of Jena, Jena, Germany
}

\begin{abstract}
The Porifera represent one of the only two recent nerveless and muscleless metazoan phyla. Nevertheless, sponges provide behavioral, physiological, pharmacological, morphological, and, more recently, an increasing amount of genetic evidence for a paracrine pre-nervous integration system. Although this system might be derived, it allows us to draw conclusions, on the basis of comparative data, about the origin of the nervous system sensu stricto as found in the eumetazoan phyla. The goal of the present review is to compile recent evidence on the sponge integration systems. Based on this framework, new light is also shed on the evolutionary origin of the eumetazoan synaptic nervous systems, which can be regarded to form an evolutionary biochemical continuum with the paracrine signaling system in sponges. Thus, we can assume that the evolutionary transition from a paracrine-dominated, pre-nervous system to an electrochemically dominated, primordial nervous system resulted in part from compartmentalization effects. As intermediate evolutionary stages, regionalized synapse precursor areas might have occurred within pre-nervous cells, which foreshadowed the highly organized synaptic scaffolds present in recent nerve cells of the Eumetazoa.
\end{abstract}

Additional key words: pre-nervous system, sponge contraction, synapse, paracrine

\section{Background}

Metazoan nervous systems are structurally and functionally diverse, and generally highly complex. Even the simplest nervous systems, the nerve nets in the Cnidaria and Ctenophora, display a structural complexity on the cellular and sub-cellular level that implies a long evolutionary history. The evolution of the central nervous systems of the Bilateria is generally better understood than the evolutionary origin of the nervous system (Hanström 1928; Bullock \& Horridge 1969; Schmidt-Rhaesa 2007). Most research focuses on excitability in the context of "simple" nerve nets in Cnidaria, and on the properties of the neurons involved in such nets (Parker 1910, 1919; Pantin 1952, 1956; Passano 1963; Mackie 1970; Meech \& Mackie 2007). In some hydrozoan medusae, the degree of organization within the nervous system and the linked myoepithelia is remarkably high, and facilitates differentiated swimming behaviors (Meech \& Mackie 2007). Studies of the nervous systems in Cnidaria and Ctenophora will certainly shed light

\footnotetext{
a E-mail: m.nickel@uni-jena.de
}

on the early evolutionary diversification of nervous system elements. However, in order to understand the origin of nervous systems in the widest context, we must also investigate pre-nervous systems.

A nervous system is absent in sponges (Jones 1962; Mackie 1990; Leys \& Meech 2006). However, morphological (Lentz 1966, 1968; Weyrer et al. 1999), physiological (Ellwanger \& Nickel 2006; Elliott \& Leys 2007; Ellwanger et al. 2007), and genomic evidence (Perovic et al. 1999; Nichols et al. 2006; Jacobs et al. 2007; Sakarya et al. 2007; Richards et al. 2008; Kosik 2009) suggests that a poriferan integration system comprises modules that might be homologous to modules in recent nervous systems.

The nervous system sensu stricto is an autapomorphy of the Eumetazoa (for overviews, see Hanström 1928; Bullock \& Horridge 1969; Schmidt-Rhaesa 2007) and can be defined as a system that conducts information in a directed way through the body via electrical and/or chemical signals, and cells specialized for these functions (Schmidt-Rhaesa 2007). This definition includes spatial and temporal aspects. To our knowledge, sponges do not possess such a directed signaling system. In contrast, a second definition, the neuron doctrine, is strictly mor- 
phology-based and does not consider the nature of the signal (Ramon y Cajal 1937), and maintains that all nervous systems consist of distinct cells known as neurons, which are specialized for nervous functions and that produce prolongations and branches (Bullock \& Horridge 1969). Historically, the latter, very formal, definition raised the question of whether there is actually a nervous system in the Porifera. In fact, prolonged and branched cells, which might temporarily interconnect, are present in the mesohyl of many sponges (e.g., Pavans de Ceccatty 1959). However, they lack other typical nerve cell characteristics, such as synapses and defined networks of prolonged cells.

The evolution of the nervous system has been discussed in depth by various authors, some of whom were influenced by the morphological and behavioral evidence from sponges discussed below. The most influential concepts go back to the Hertwig brothers (Hertwig \& Hertwig 1878), Parker (1910, 1919), Pantin (1952, 1956), Grundfest (1959, 1965), Passano (1963), Lentz (1966, 1968), Horridge (1968), and Mackie (1970, 1979, 1990). These concepts are only outlined here; for details, refer to the original publications or some excellent in-depth reviews (e.g., Jones 1962; Leys \& Meech 2006; Lichtneckert \& Reichert 2007; Meech \& Mackie 2007). Most of these concepts focus on the evolution of excitability in Metazoa. The neuron concept (i.e., Ramon y Cajal 1937; Barbara 2006) has played a major role in hypotheses on nervous system evolution (e.g., Parker 1910, 1919; Hanström 1928; Pantin 1952, 1956; Grundfest 1959, 1965; Jones 1962; Passano 1963; Bullock \& Horridge 1969; Mackie 1979, 1990; Leys \& Meech 2006; Leys 2007; Meech \& Mackie 2007; Schmidt-Rhaesa 2007).

The evolutionary key novelty of a spatio-temporal information organizer such as the Eumetazoan nervous system sensu stricto seems to be the synapse, for the following reasons. (1) The synapse allows mainly uni-directional information transfer, based on chemical messengers. Thus, synapses represent a derived form of paracrine signaling; although chemical information transfer is temporally limited by diffusion, the synapse might be considered a fast system, because diffusion distances are structurally minimized by the synaptic cleft. (2) The synapse is the interface between two individual cells, which distribute electrochemical information by local potential changes over their cell bodies, along their cell membranes. In the earliest concepts on the origin of the nervous system, however, the term "synapse" and the concept of connectedness (Sherrington 1897) did not play a central role, whereas the evolution of "receptor" and "effector" elements was essential. Hertwig \& Hertwig (1878) assumed that muscle cells, sensory cells, and ganglion cells evolved from a constant interaction between indifferent epithelial cells. Parker (1919) suggested that independent primitive receptor-effector cells received stimuli and reacted with the appropriate activity, i.e., contraction. During evolution, receptors and effectors would have been separated in space and structure, but remained connected through axons.

Which evolutionary sequence resulted in the morphologically and physiologically highly specialized nervous system? Grundfest suggested that neurosecretion - not contraction - was the ancient effector activity of primitive receptor-effector cells (Grundfest 1959). Lentz referred to this concept in his demonstration of transmitter activity in sponges (Lentz 1966, 1968), concluding that synapses must be present in sponges. However, there is no ultrastructural evidence of synapses in sponges (Jones 1962; Simpson 1984; Mackie 1990; Leys 2007; Meech \& Mackie 2007).

The question arises as to how the synapse might have evolved. Considering it as a highly specialized paracrine information transmission system, we might regard a more general paracrine system as the origin of the synapse. Such paracrine systems are present in unicellular eukaryotes, but also in the asynaptic, nerveless, sponges. The latter, like all other early branching metazoans, are evolutionarily derived. The sponge integration system thus represents a derived state, which likely differs from the integration system of the early stem group metazoans. The aim of this review is to provide evidence for a scenario on the evolution of synaptic nervous systems from paracrine, asynaptic, pre-nervous signaling systems. Studying sponge signaling systems will thus help us to understand the transition from a paracrine to an electrochemically dominated integration system.

Here, I will provide evidence for this transition by evaluating recent results from morphological, physiological, and genomic studies on sponges. I will summarize behavioral evidence for integration in sponges by focusing on contraction phenomena, followed by a discourse on the non-muscular contractile effectors and putative sensory cells in sponges. I will briefly discuss morphological evidence for a sponge integration system. The main focus will subsequently be on the physiology and genomics of sponge electrochemical and paracrine signaling. This will lead me to an outline of an extended hypothesis on the origin of synaptic nervous systems, with a focus on the transition from paracrine to electrochemical dominance within metazoan integration systems. Finally, I will conclude with some notes on how our understanding 
of animal phylogeny will influence our understanding of the early evolution of the nervous systems.

Following recent publications, I consider sponges to be monophyletic, with Hexactinellida and Demospongiae sensu stricto branching first and forming the monophylum Silicea. Silicea are separated from Homoscleromorpha and Calcispongia (Calcarea), which in turn seem to be sister groups (Philippe et al. 2009). This particular phylogeny implies that data from any of the four higher poriferan taxa are important for our understanding of the origin of metazoan integrative systems.

\section{Integration: rhythmic contraction patterns}

A high percentage of sponges, if not all, are able to contract their body or parts of it (e.g., oscula or canals). In this section, I will provide evidence of why poriferan contraction is relevant to the question of an integrative system in this phylum.

Contraction is frequently found in Demospongiae (e.g., Schmidt 1866; Marshall 1885; Arndt 1941; Nickel 2004; Fig. 1A), Homoscleromorpha (e.g., Oscarella lobularis [SснміDт 1862], unpubl. data; Fig. 1B), and Calcispongia (Minchin 1900; Fig. 1C). No contraction has been reported in Hexactinellida to date, which is not surprising, considering their rigid skeletons and the relatively low amount of cellular mass and extracellular matrix they possess in relation to the silica skeleton (Leys et al. 2007). However, the same can be said of a number of clades in Demospongiae. Those with rigid, spicule-rich skeletons, such as members of Petrosiidae or Suberitidae, do not display significant external body contractions. Nevertheless, most species in these groups will display both oscular contractions and internal contractions of the aquiferous system (unpubl. data, X-ray microtomography measurements on specimens of Suberites domuncula). This latter phenomenon is very similar to the internal contractions in sponge species without such massive, rigid skeletons, and that do display external body contractions, e.g., Ephydatia mülleri (LieberKüHN 1855) (Elliott \& Leys 2007). Whether members of Hexactinellida are able to perform such internal contractions remains to be shown.

Three observations clearly demonstrate that poriferan contraction is controlled by an integrative system. (1) Contractions always occur rhythmically (Fig. 1: third column; see also Movies S1-S3 available as supporting information). An endogenous rhythm is present in members of Demospongiae (Weissenfels 1984; Nickel 2004; literature cited in both), and recent preliminary studies show the same
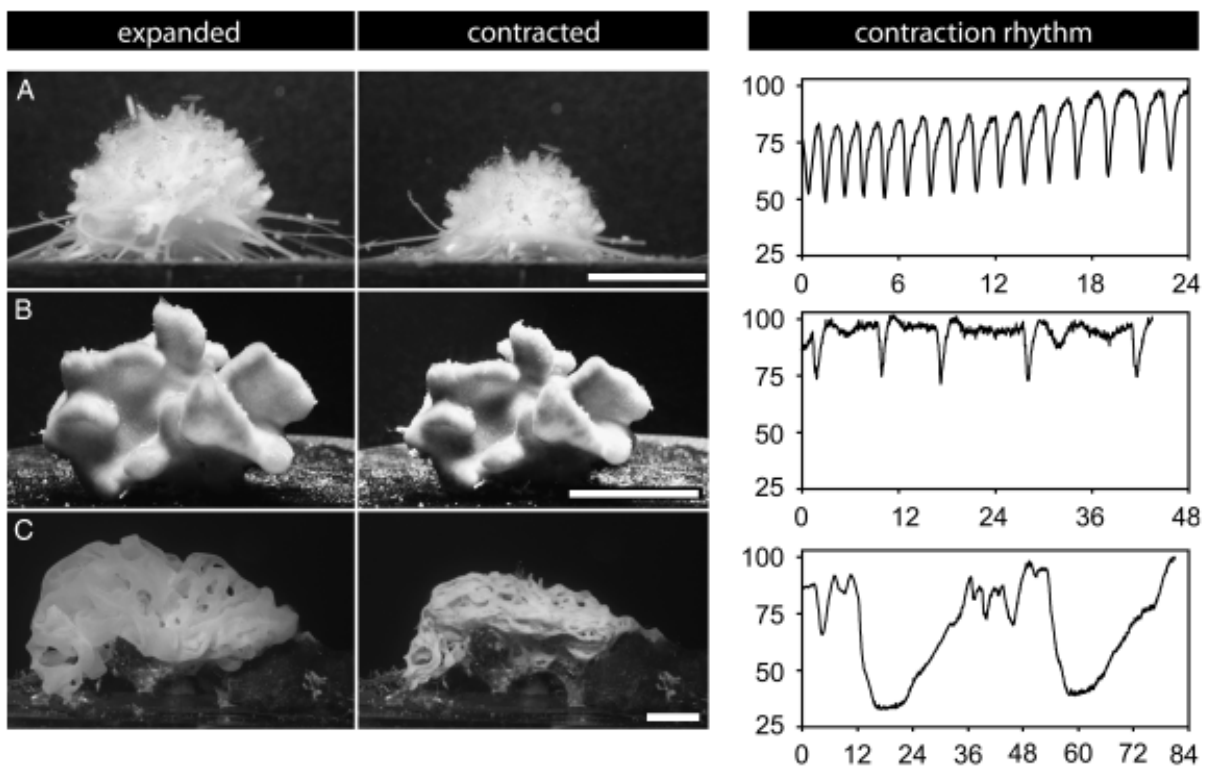
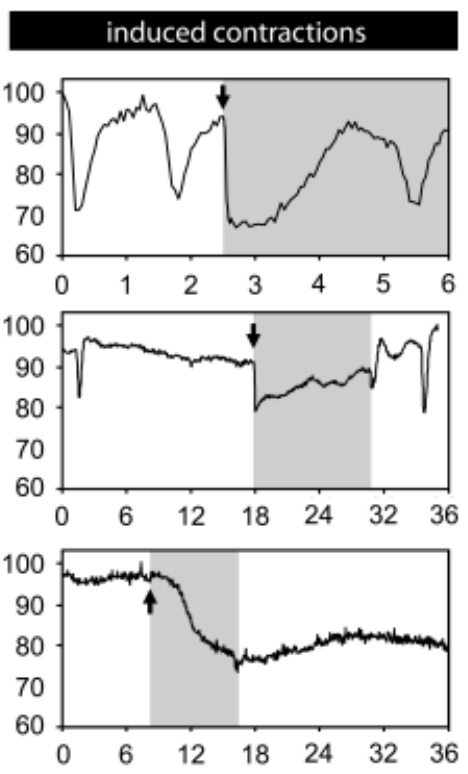

Fig. 1. Contraction in three of the four poriferan lineages. A. Demospongiae: Tethya wilhelma; B. Homoscleromorpha: Oscarella lobularis; C. Calcispongia: Clathrina clathrus (Schmidt 1864). Columns 1 and 2: habitus of expanded and contracted states (scale bars $=5 \mathrm{~mm}$ ). Column 3: long-term contraction pattern displayed as relative projected area (arbitrary units) over time (h). Column 4: induction of contraction (arrows) by $\gamma$-amino butyric acid (A) and glutamate (B,C). For the methodology, see Ellwanger \& Nickel (2006). Time-lapse movies of contractions in all three poriferan lineages are available as supporting information Movies S1-S3; for movie methodology, see Nickel (2004) and Ellwanger \& Nickel (2006). Data and images: A1-4, Ellwanger \& Nickel (2006); B1-4 and C3, 4: A. Arnold, pers. comm.; C1, 2: unpubl. data. 
for those of Homoscleromorpha and the Calcispongia (Fig. 1B,C: third column; C. Arnold \& M. Nickel, unpubl. data). (2) Demosponges react to some external mechanical stimuli in situ and in vitro with immediate contraction (Nickel 2004; Elliott \& Leys 2007). (3) Transmitter substances sensu lato induce contractions in Demosponges (Ellwanger \& Nickel 2006; Elliott \& Leys 2007; Ellwanger et al. 2007). Again, recent preliminary studies have demonstrated the same in the Homoscleromorpha and the Calcispongia (Fig. 1B,C: third column; C. Arnold \& M. Nickel, unpubl. data).

In addition to these regular patterns, local contractions occur constantly over the sponge surface. Modern time-lapse imaging makes sponges appear almost wriggly - at least in the context of their slow biological lifetime (see the movies in supporting information, and the supplementary movies of Nickel 2004; Ellwanger \& Nickel 2006; Ellwanger et al. 2007). Since natural and induced contractions and the patterns of contraction rhythm are experimentally readily addressable and quantifiable (Nickel 2004), contraction is presently "the" marker in studying and manipulating the effects of the putative poriferan integrative system (Ellwanger \& Nickel 2006; Ellwanger et al. 2007).

\section{What is the non-muscular contractile effector?}

Contractility and integration are generally considered to co-evolve (e.g., Mackie 1970), raising the question on the nature of the non-muscular contractile effector cells in the Porifera. The following paragraph discusses two alternative hypotheses. In addition, I address the confusing use of the terms "actinocyte" and "myocyte."

Two competing hypotheses on the nature of poriferan contractile effector cells were postulated early on (for a detailed overview, see Jones 1962). The first hypothesis centered around mesohyl mediated contraction originating in "myocytes" (Schmidt 1866; Sollas 1888), and was based on the smoothmuscle-like appearance of the cells concerned and the presence of actin bundles (Bagby 1966). This cell type was found in many sponge species and accepted as a contractile effector on the basis of its shape characteristics (Prosser et al. 1962; Lentz 1966, 1968; Vacelet 1966). "Myocytes" were also interpreted as evolutionary prototypes of neuromuscular cells (Pavans de Ceccatty 1960, 1971, 1974, 1979). Problematically, the hypothesis is not supported by functional or in-depth morphological studies regarding the contractility of "myocytes" (Jones 1962; Nickel 2004). The terminology is also confusing; while most of the older literature uses "myocyte," the term was ultimately rejected as misleading due to the lack of proof of contractility and the neutral term "actinocyte" introduced instead (Boury-Esnault \& Rützler 1997). Although the majority of recent sponge scientists prefer the term "actinocyte" (e.g., Nickel 2004), its synonym "myocyte" remains in use (e.g., Elliott \& Leys 2007).

The second hypothesis holds that epidermal contraction originates in pinacocytes and is mainly based on observations of living and fixed material (Minchin 1900; Parker 1910; Wilson 1910; Bidder 1937; Jones 1957). The hypothesis is supported by the presence of actin filaments (Bagby 1970; Matsuno et al. 1988).

The two hypotheses were combined into more complex and thus probably more realistic models of sponge contraction (Pavans de Ceccatty 1981, 1986), but the problem has not been addressed in depth over the last two decades, despite the advances in livecell imaging and genetic manipulation techniques in biology.

Recently, we were able to provide indirect evidence that the pinacoderm is important in poriferan contraction. We used microtomography (Nickel et al. 2006a,b, 2008) to compare an expanded and a contracted specimen of Tethya wilhelma SARÀ, SARÀ, Nickel, \& BRÜMMER, 2001 (Fig. 2A,B; see also Nickel, et al. 2006c). Three-D morphometrics revealed that, during contraction, the canal volume is reduced almost exclusively, while the mesohyl remains constant or even expands slightly (Fig. 2C; M. Nickel, Scheer, Hammel, Herzen, \& Beckmann, unpubl. data). This can most easily be explained by a contractile (endo-)pinacoderm. In-depth studies on the histology and ultrastructure of contraction in T. wilhelma are in progress. Additionally, new data provide evidence of tighter and more stable connections between pinacocytes than previously assumed (Leys et al. 2009). The stability of the various types of poriferan epithelial tissues (in the sense of Leys et al. 2009) is a prerequisite for the biomechanics of epithelial contraction (Weissenfels 1989). However, these new results do not exclude mesohyl contraction, which can be seen in freshwater sponges (e.g., Elliott \& Leys 2007). The most likely scenario seems to be a combination of pinacoderm and mesohyl contraction, with the mesohyl playing a much more prominent role than generally assumed.

How is non-muscular contraction in sponges generated on the sub-cellular level? Is myosin involved? Genomic studies on Amphimedon queenslandica HooPER \& VAN SOEST, 2006 recently revealed orthologs of bilaterian smooth muscle-like and skeletal musclelike myosin II heavy-chain genes (Steinmetz et al. 2008). It will be most interesting to determine which 

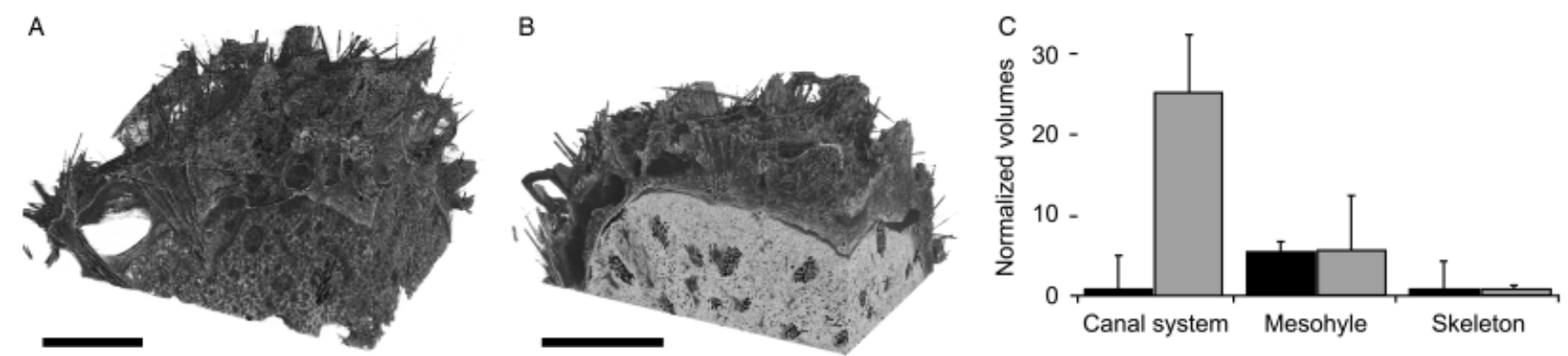

Fig. 2. Contractility in Tethya wilhelma assessed by microtomography: A,B. Virtual 3D reconstructions of two specimens (A, expanded; B, contracted). Scale bars $=1000 \mu \mathrm{m}$. C. Comparative volumetric analysis of body compartments in a contracted (black) and expanded (gray) specimen of $T$. wilhelma. Only the canal system volume changes during contraction, while the volume of the mesohyl remains almost constant. Data were normalized on the basis of the skeleton volume proportions, which we assumed to be almost constant between specimens (unpubl. data; for methodology, see Nickel et al. 2006a, 2008).

adult cell types express these genes and whether they are connected to contractile behavior. However, neither their specific sequences nor the annotated draft of the genome of Amphimedon have been published as yet. Only the genome trace files are currently accessible (A. queenslandica aka Reniera sp. JGI-2005 WGS, searchable and downloadable at http:// trace.ensembl.org/ and http://www.ncbi.nlm.nih. gov/Traces).

\section{Are there specific sensory cells in sponges?}

As we have seen, sponges react to external stimuli. The question of sensory or receptor cell types has been addressed in depth by previous reviewers (Jones 1962; Leys \& Meech 2006; Renard et al. 2009). No specialized sensory cell type has been found in sponges to date. However, it has been suggested recently that choanocytes may serve as sensory cells inside sponges, (1) because of their morphological similarity to eumetazoan sensory cells and (2) because of the sensory array-like organization of choanocyte chambers (Jacobs et al. 2007). This concept was recently backed up by sponge genome and EST data, which reported orthologs of eumetazoan sensory and nerve cell-specific genes (Nichols et al. 2006; Jacobs et al. 2007; Sakarya et al. 2007; Kosik 2009).

Another promising sensory-cell-type candidate is present in the aquiferous system of sponges. Some endopinacocytes are mono- or bi-ciliated (Sollas 1888; Pavans de Ceccatty 1960; Nickel 2006a; Leys et al. 2009; see Fig. 3). The cilia are short $(<5 \mu \mathrm{m}$; Fig. 3C) and so widely spaced (Fig. 3A,B) that they are highly unlikely to be involved in the production of water currents. Instead, they resemble mechanosensilla or primary cilia (Satir \& Christensen 2007). This cell type is currently under investigation (Leys et al. 2009; unpubl. data). It will be interesting to find out more about the functional physiology and the gene expression profile of this type of cell, in order to link it conceptually to a putative poriferan integrative system.

Another sensory-cell-type candidate is the monociliated globular cell found in demosponge larvae, which are sometimes referred to as "mucous cells" (Leys \& Degnan 2001; Richards et al. 2008; Renard et al. 2009). This cell type expresses orthologs of bilaterian proneural genes, such as a basic helix loop helix gene and the Notch-Delta signaling system (Richards et al. 2008). However, the role of globular cells in demosponge larvae has not been investigated in detail functionally.

From the given evidence, it is likely that sponges possess specific cellular sensors. Whether they are specialized sensory cells or resemble more closely the prototypic receptor-effector cell types, sensu Parker (1919) and Grundfest (1959), remains to be investigated.

\section{Morphological basis for an integration system}

What evidence can morphology provide in our stocktaking of the putative poriferan integrative system? Cell-cell connections likely play a role in this system, and so the morphological pattern of sponge cell types is important. Bi- and multi-polar cell types are frequently found within the mesohyl, and their histology has been addressed in depth (Pavans de Ceccatty 1959, 1960, 1979; Jones 1962; Simpson 1984; Nickel 2004). Even though morphological characteristics such as these are reminiscent of nerve cells, this is probably a misleading avenue to go down. Many "nerve cell-typical" properties are foreshadowed in non-nervous tissue (Meech \& Mackie 

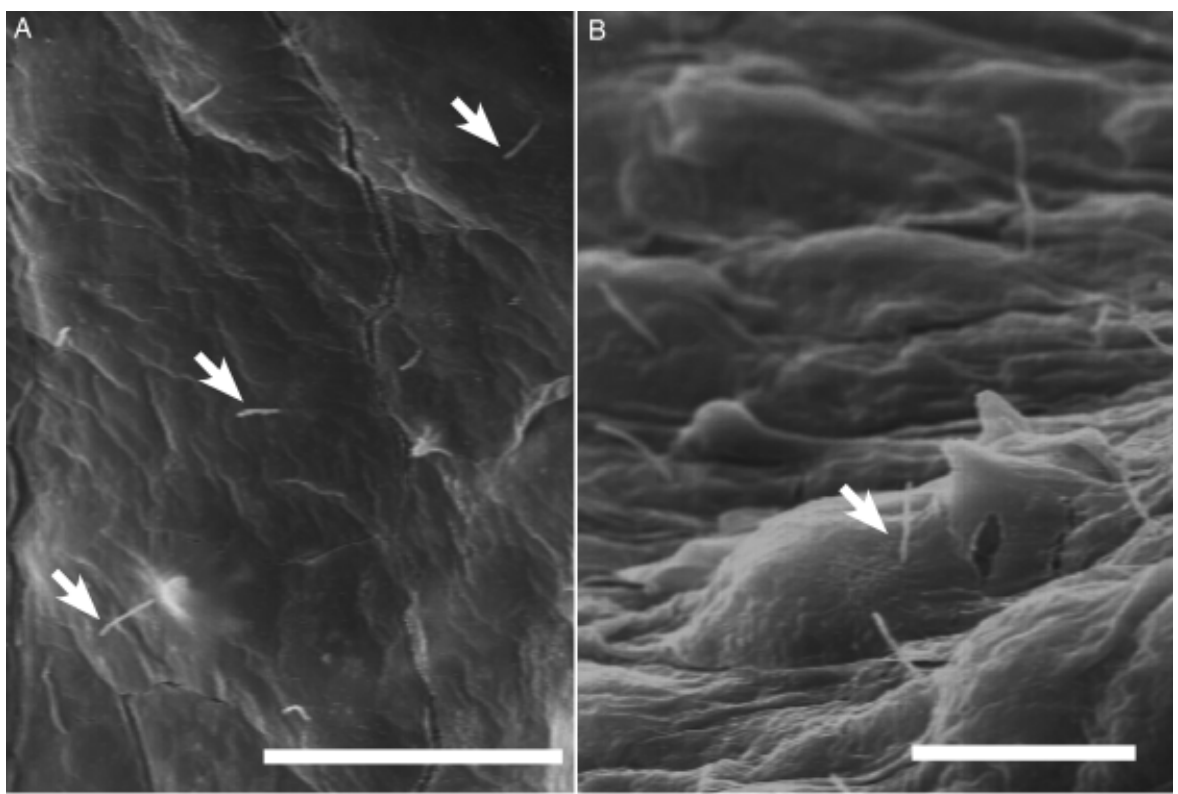

Fig. 3. A putative poriferan sensory cell: scanning electron microscopic images of monociliated endopinacocytes from the excurrent canal system of Tethya wilhelma. A,B. Views of the widely spaced cilia (arrows; distance between cilia: 15-30 $\mu \mathrm{m})$. C. Detail of a single cilium: located in a depression (arrow), slightly bent, and $<5 \mu \mathrm{m}$ long. Scale bars $=25 \mu \mathrm{m}$ (A), $10 \mu \mathrm{m}$ (B), and $1 \mu \mathrm{m}$ (C). Modified from Nickel

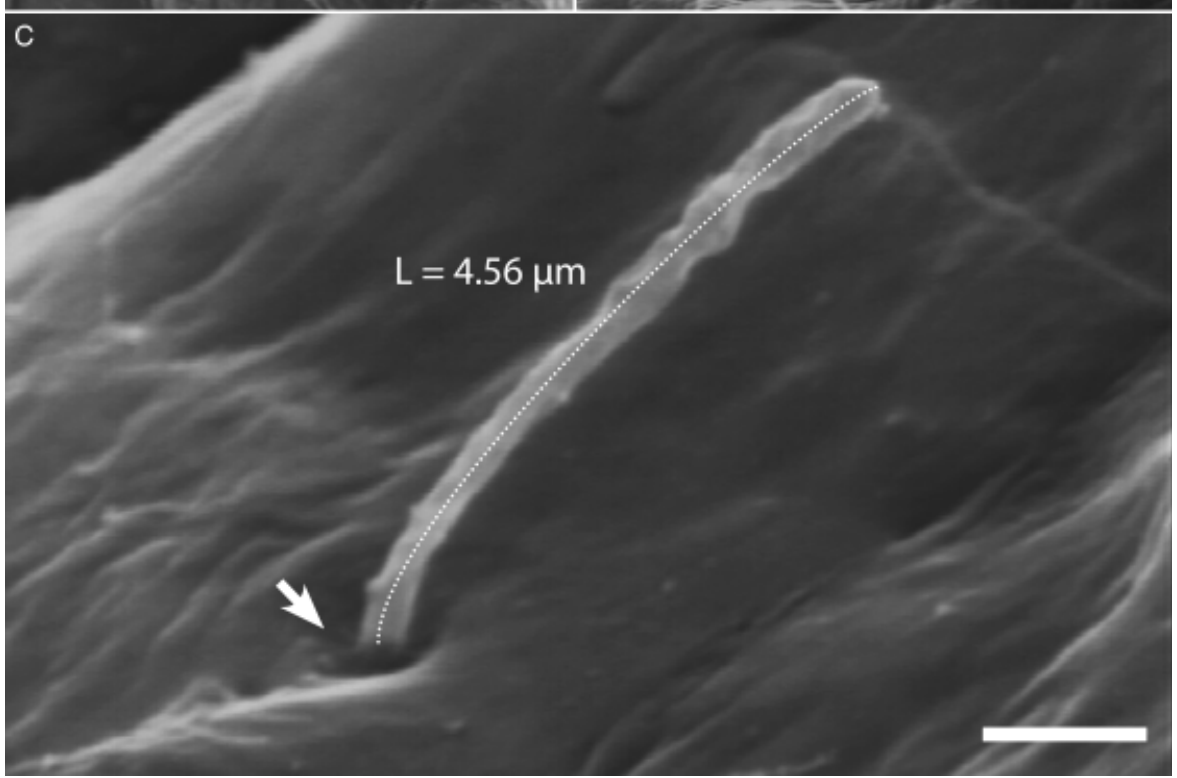
(2006a,b).

2007) and are thus not eligible as characteristics to identify nerve cells morphologically.

It has been shown that most cell types are permanently motile (Bond 1992; Nickel \& Brümmer 2004), and so it might well be useful to consider spatio-temporal effects such as transient cell-cell contacts. Transient cell-cell contacts would make permanent long-distance wiring via synapse-like structures unlikely, although such structures may have been implicated by recent genomic studies (Sakarya et al. 2007; Kosik 2009). On the other hand, two recent findings should be considered in this context. (1) Poriferan pinacoderm epithelia are spatio-temporally stable structures (Leys et al. 2009). (2) Transient cell- cell contacts are formed among mesohyl cells (Bond 1992; unpubl. data). The nature of these transient contacts remains to be specified. Both the stable and the transient contacts might involve structural elements of the post-synaptic scaffold, pre-synaptic, vesicular traffic, and elements of the axonal guidance pathways. However, this is speculative and will have to be investigated.

\section{Physiology and genomics of integration in sponges}

The investigation of electrochemical phenomena in sponges is still in its infancy. Hexactinellids are 
known to use action potentials (Leys \& Mackie 1997, 1999; Leys et al. 1999), which demonstrates that electrochemical integration occurred early in the metazoan lineage. However, electrical impulses seem to be absent in demosponges and calcisponges (Meech \& Mackie 2007). Some evidence for electrical coupling and the presence of voltage, and ligand-dependent and mechano-sensitive ion channels, has been provided (Zocchi et al. 2001; Meech \& Mackie 2007; Tompkins-MacDonald et al. 2009), although not all of it seems to be flawless (e.g., the data of Loewenstein 1967). Electrochemical integration phenomena in sponges have been discussed in detail (see the reviews by Leys \& Meech 2006; Lichtneckert \& Reichert 2007; Meech \& Mackie 2007). Therefore, I only address recent evidence from genomic and functional studies.

Within the post-synaptic gene repertoire present in the genome of $A$. queenslandica, ion channels such as the plasma membrane $\mathrm{Ca}^{2+}$ ATPase (AmqPMCA) and inward-rectifier potassium ion channels (AmqKir) are present (Sakarya et al. 2007). No techniques are currently available for performing electrophysiological studies in demosponges (Leys \& Meech 2006; Leys 2007; Tompkins-MacDonald et al. 2009) in order to investigate such ion channels directly. Nevertheless, in a pioneering study using the functional expression of sponge cRNA injected into oocytes of Xenopus, the AmqKirA and AmqKirB channels mentioned were characterized (TompkinsMacDonald et al. 2009). Their pore properties demonstrated strong $\mathrm{K}^{+}$selectivity. The channel was blocked by $\mathrm{Cs}^{2+}$ and $\mathrm{Ba}^{2+}$. Both the amino acid sequence and the physiology demonstrated a high level of conservation of structure and function throughout all metazoans, and imply that some demosponge cell membranes are specialized for electrochemical signaling. The study by Tomkins-MacDonald and coauthors demonstrates that integrative approaches that combine genomics and physiology will increasingly influence our understanding of a sponge pre-nervous system.

The same applies to the study of the poriferan paracrine signaling system. Earlier pharmacological studies have been thoroughly reviewed (Jones 1962; Mackie 1979; Pavans de Ceccatty 1979; Leys \& Meech 2006; Nickel 2006b; Leys 2007; Meech 2008). Table 1 provides a cumulative overview of important putative receptor systems present in the paracrine signaling repertoire of sponges, and sums the physiological and genomic evidence presented so far. It is evident that a wide variety of paracrine pathways are present in sponges despite the fact that the behavioral repertoire of sponges is relatively limited. Typical behaviors are contraction of canal system elements or the whole body, closure of ostia and oscula, arrest of pumping activity, and extension or retraction of body filaments (Simpson 1984; Nickel 2004; Nickel \& Brümmer 2004). Some behaviors seem to be under the direct control of a number of paracrine pathways. One example is the immediate induction of contraction in $T$. wilhelma by amino acid transmitters such as $\gamma$-amino butyric acid (GABA) and glutamate, and by the monoamine neurotransmitter serotonin (Ellwanger \& Nickel 2006; Ellwanger et al. 2007). On the other hand, some transmitters such as glycine or acetylcholine result in delayed inductions and/or strong effects on internal endogenous rhythms, but also on overall contraction amplitudes (Ellwanger \& Nickel 2006). Putatively, these messengers do not act directly on the contractile cells, but eventually on cellular systems involved in endogenic rhythm control (pacemakers).

Some of these signaling pathways were recently recovered in the genome of $A$. queenslandica, namely the gene orthologs from GABAergic, glutamergic, and nitric oxide pathways (Sakarya et al. 2007). Interestingly, the receptors of these pathways seem to be structurally organized into a post-synaptic-scaffold-like network based on PDZ domains and ligands. Comparative genomics suggest that the whole structure is organized almost like in the synapse of Eumetazoans, with a not-yet complete set of genes (Sakarya et al. 2007; Kosik 2009). It will be interesting to shed light on the sub-cellular distribution of these sponge post-synaptic scaffold-like structures in future studies. From the present evidence, I doubt that the spatial organization and distribution of this structure will morphologically be similar to those of a synapse.

Comparative physiology, biochemistry, and genomics strongly suggest that the paracrine secretory pathways in the Porifera and the transmitter pathways in synapses of the Eumetazoa represent an evolutionary biochemical continuum, without sharing the degree of spatial organization. This is not surprising, because transmitter substances play important roles in unicellular eukaryotes, and thus are evolutionarily ancient (Walker \& Holden-Dye 1991; Walker et al. 1996). It currently seems that in the Porifera, and probably also in extinct early metazoan stem groups, the integrative system was dominated by paracrine signaling (i.e., the release of signal substances into the extracellular matrix). The relevant messengers most likely first acted as autocrine or intracrine messengers in unicellular eukaryotes (e.g., compare Ramoino et al. 2003, 2004, 2005), a function that was further refined during the early evolution of 


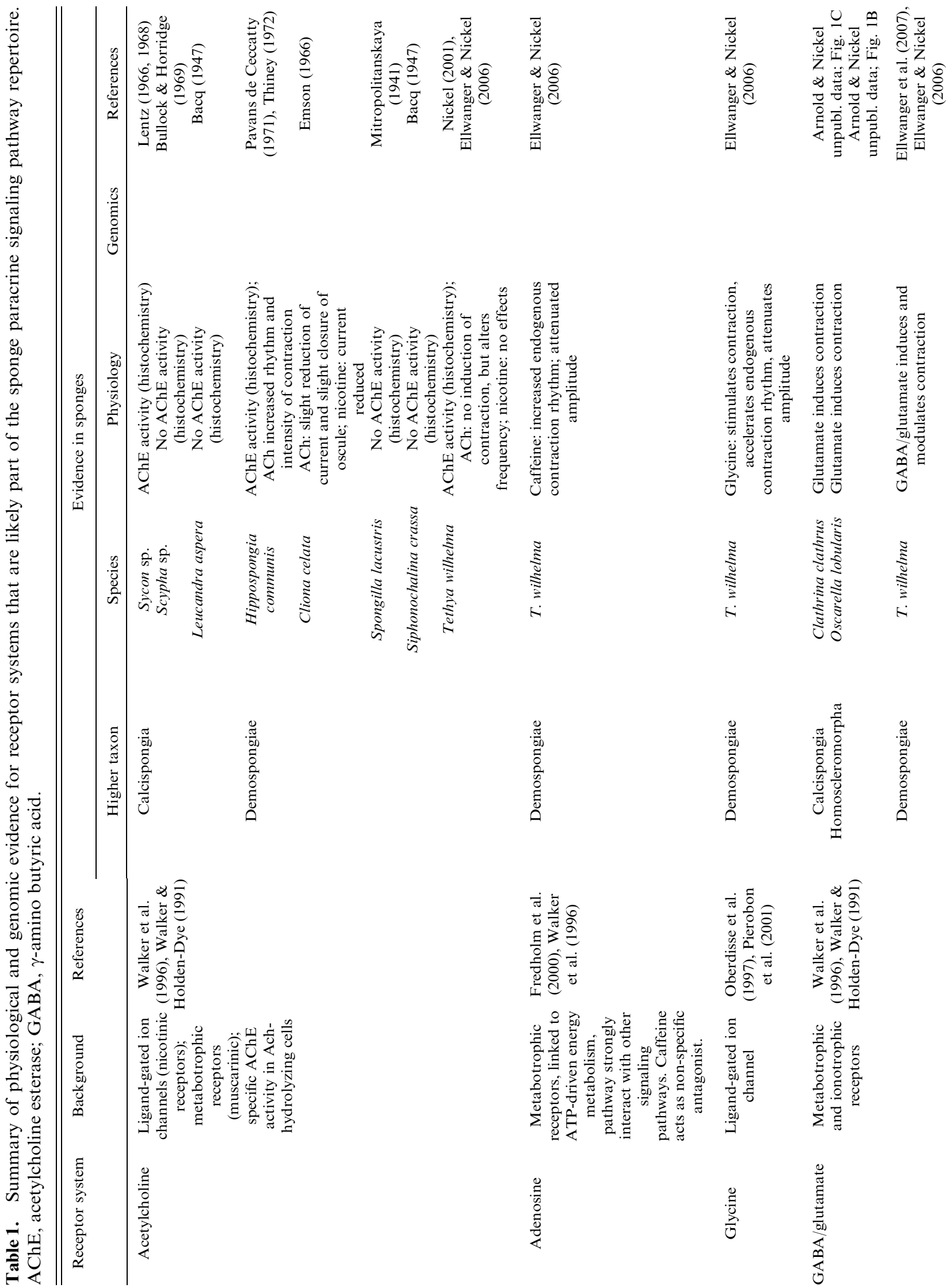



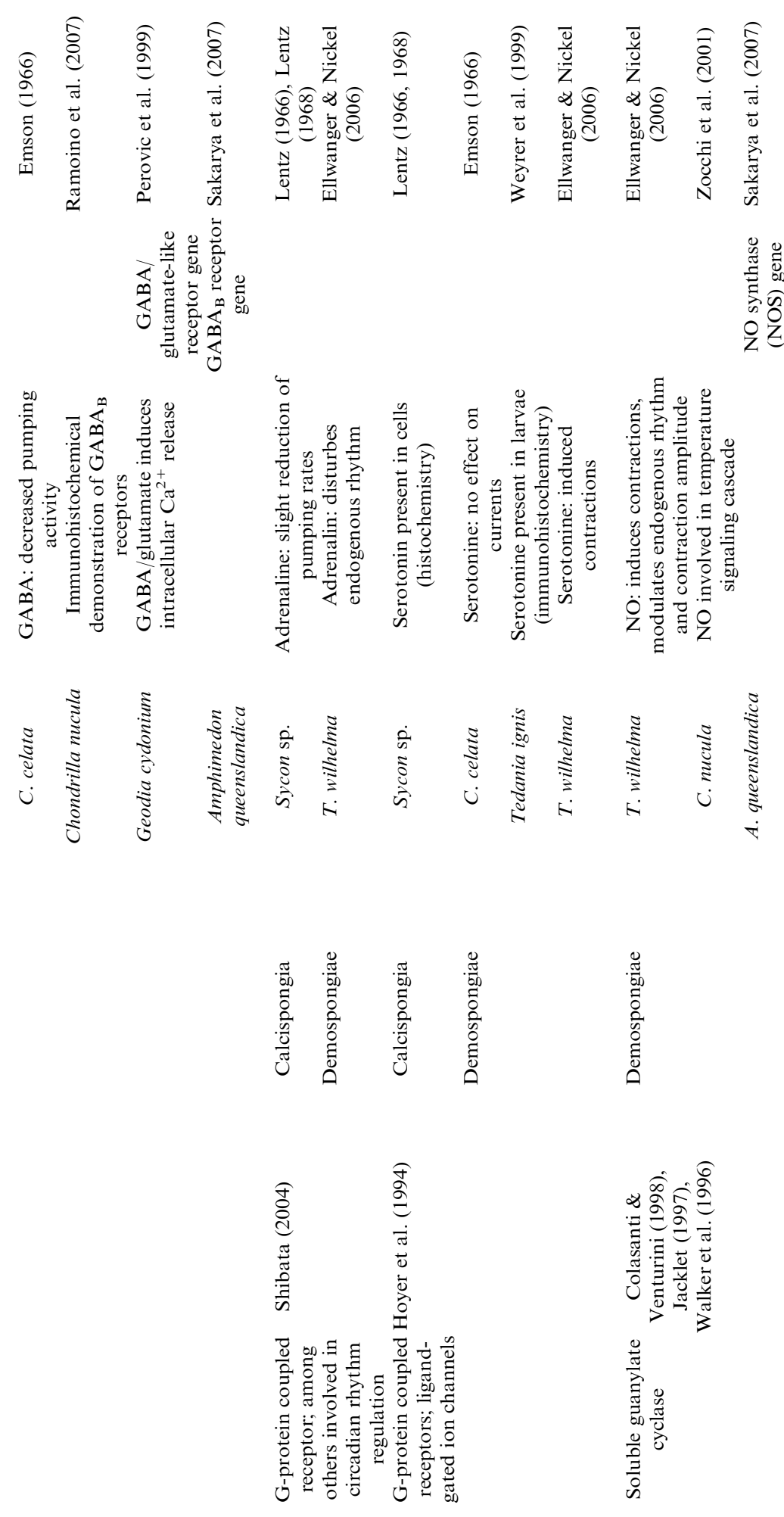

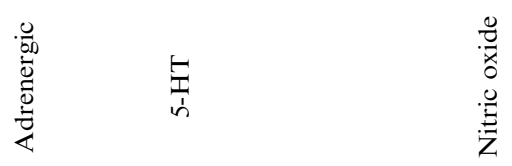


the Metazoa. Certain constraints during the early evolution of the Metazoa seem to have favored (1) directed communication and (2) faster communication (in comparison with the diffusion of molecules). This entailed cellular specialization and compartmentalization and a transition, in terms of temporal and spatial dominance, from paracrine signal transduction to electrochemical signal transduction. These assumptions might be compiled into a hypothesis regarding the early evolution of a (pre-) nervous integration system that combines the views of Grundfest (1959) with those on the compartmentalization of signaling in neurons (Mattson \& Bruce-Keller 1999), genomic evidence (Jacobs et al. 2007; Sakarya et al. 2007; Kosik 2009), histological and morphological evidence (as reviewed by Jones 1962; Pavans de Ceccatty 1979, 1989; Simpson 1984), and physiological evidence (e.g., see Lentz 1966, 1968; Ellwanger \& Nickel 2006; Leys \& Meech 2006; Ellwanger et al. 2007).

\section{Origin of the synaptic nervous system}

The following outline is compared schematically with the neuro-muscular hypothesis on the evolution of the nervous system (Mackie 1970) in Fig. 4. The axioms for the extended hypothesis are available as supporting information Text S1. In contrast to Parker (1919), and following Hertwig \& Hertwig (1878), I assume that highly specialized contractile effectors (muscle cells), sensory cells, and ganglion cells evolved in parallel from non-specialized epithelial cells. The spatial concentration of contractile cells into defined cellular layers and eventually contractile cellular sheets could have spurred the co-evolution of faster contraction mechanisms and directed intercellular communication. It is likely that the evolution of these cellular differentiations is linked to the evolution of the mesoderm, although this remains to be proven. The evolutionary origin of the mesoderm is also still under discussion (Spring et al. 2002; Martindale et al. 2004; Seipel \& Schmid 2006).

The trophic and morphogenetic effects of various neurosecretory molecules predated the evolution of their transmitter function. They modulated the growth and elongation of cells, frequently guided by gradients of neurosecretions. Like all other cells, elongated cells were capable of reception and neurosecretion. If faster signaling was favored by evolutionary constraints, the structural accumulation of membrane-bound and cytoplasmic signaling pathway proteins would have enhanced the speed of intracellular signal transmission. Such intracellular accumulation might have been influenced by neuro- secretory cell guidance and tropic effects, which play important roles in all nervous systems (Walker \& Holden-Dye 1991; Walker et al. 1996; Nguyen et al. 2001; Ruediger \& Bolz 2007). However, slightly unequal distributions of secretion and receptor complexes would lead to an alteration of the neurosecretion gradient fields around the cells (Fig. 4B3). The elongation of cells and the concentration of the neurosecretory machinery toward cell ends in conjunction with electric potential changes within the cells would have had the following advantages: (1) cost-benefit for neurosecretion would increase due to localization, (2) the temporal dominance of messenger diffusion would be balanced by a higher spatial share of the faster intracellular electric conduction, and (3) autocrine effects (external feedback loops) would be minimized. A decrease in the distance between the site of neurosecretion and putative receptor sites in neighboring cells would result in further benefits: (1) it would increase signal specificity, (2) it would further increase cost-benefit by decreasing dilution over diffusion distance, allowing the same or even higher messenger concentrations at the receptor site to be achieved through the release of a lower total number of messenger molecules, and (3) autocrine effects would be completely eliminated in these structures, facilitating strictly directed signal transduction between single cells.

This evolutionary scenario would gradually favor further compartmentalization within the cell and thus slowly result in the assembly of pre-synaptic structures and finally synapses (Fig. 4B4). During this evolutionary course, the dominance of paracrine signal transduction in terms of time and distance ceases. In other words, the temporal and spatial share of the paracrine subsystem of an evolutionarily early (pre-) nervous system is minimized. Instead, more rapid intracellular electrical signal transduction covers larger distances between the cells, and thus attains temporal and spatial dominance within the metazoan integration system. This scenario is a pre-requisite for the evolution of spatially focused two-way transmission as found in the nerve nets of cnidarians and ctenophorans. This is also true for the polarized oneway transmission that dominates centralized nervous systems (Bullock \& Horridge 1969; Anderson 1985; Meech 2008).

\section{Phylogenetic considerations and open questions}

Can we provide phylogenetic evidence for this scenario? Will we be able to identify groups among recent Metazoa that can be regarded as representatives of intermediate stages in the paracrine-to- 

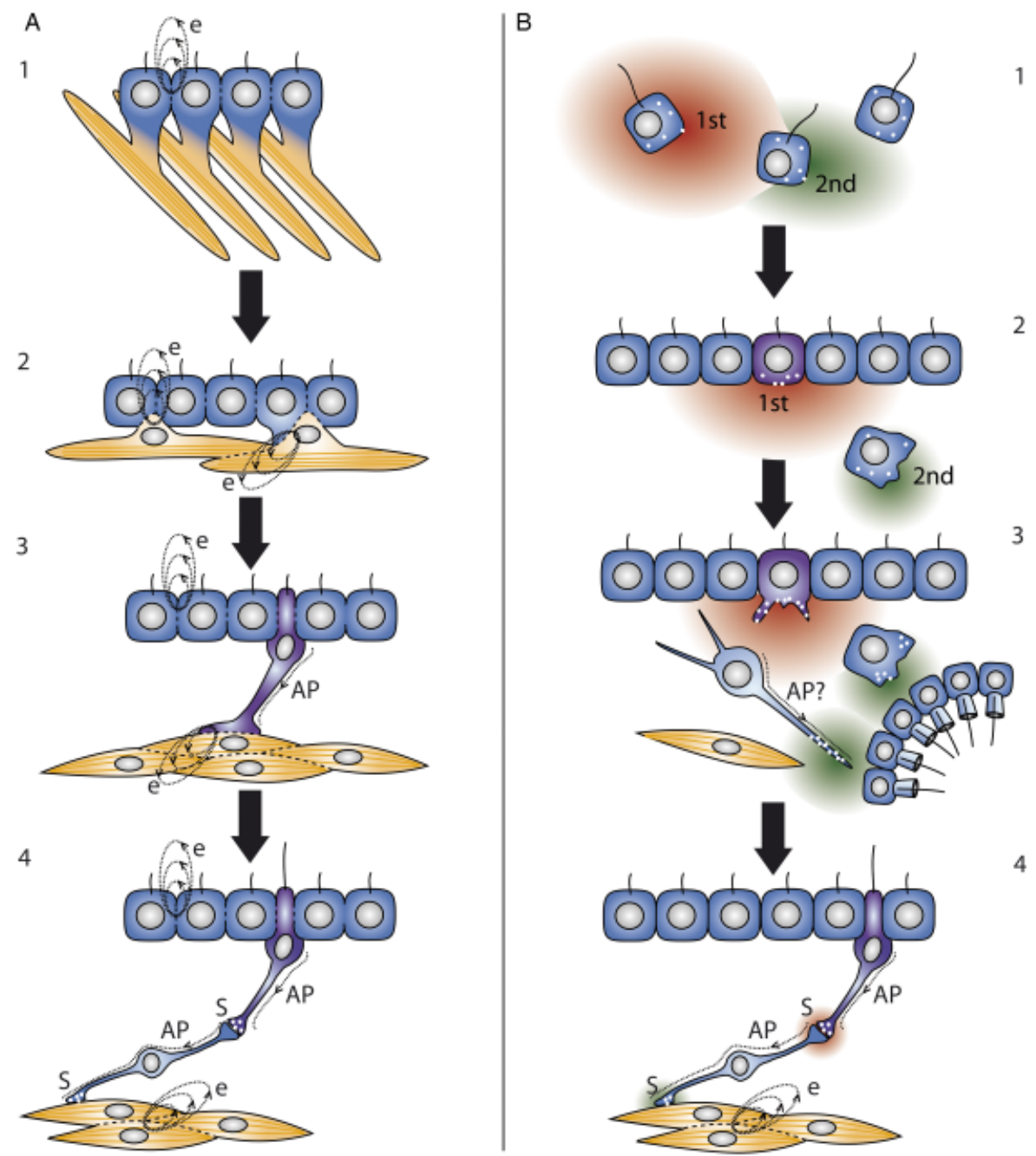

Fig. 4. Schematic comparison of two evolutionary scenarios for the nervous system. A. Neuro-muscular hypothesis (Mackie 1970, partly based on Parker 1919). (1) Primordial myoepithelium with electrically coupled (e) cells. (2) Protomyocytes start to forsake the epithelium, sinking into the interior. (3) Protoneurons evolve, conveying excitation from the exterior to the myocytes. All cells are still shown as electrically coupled. (4) Neurosensory cells and neurons evolve, which make use of AP. They are connected to one another and to the myocytes by chemically transmitting, polarized junctions. Electrical coupling persists in many epithelia and muscles. Modified from Mackie (1970) and Arendt (2008). B. Paracrine-to-electrochemical-dominance transition hypothesis as outlined in the text, partly based on Grundfest (1959). (1) Paracrine signaling in unicellular eukaryotes with signals of the first or second order. (2) Hypothetical intracorporeal paracrine signaling in early Metazoans with cascaded paracrine signals: first-order signals originate from externally stimulated epithelial cells; these signals stimulate mesenchymal cells, which release second-order paracrine signals that might be the same substance (positive feedback) or another messenger (integration). (3) New cell types evolve, with the trophic effects of paracrine messengers leading to prolonged multipolar cells. Eventually, AP are present and secretion of messengers is compartmentalized within peripheral parts of the cells (state present in sponges?). (4) Polarized and compartmentalized cells evolve into neurosensory cells and neurons, with further concentration of messenger secretion into peripheral synapse structures and AP now traveling over long distances (paracrine-toelectrochemical-dominance transition). AP, action potential; e, electrical coupling; 1st, primary chemical signal; 2nd, secondary chemical signal; $\mathrm{S}$ synapse.

electrochemical-dominance transition? Possibly not, but as I hope to have shown above, recent physiological and genomic results do qualify the Porifera as models, although some features of their paracrine signaling system may also turn out to be derived. All higher sponge taxa (Hexactinellida, Demospongiae sensu stricto, Homoscleromorpha, and Calcispongia) display pre-nervous integrative systems, but less is 


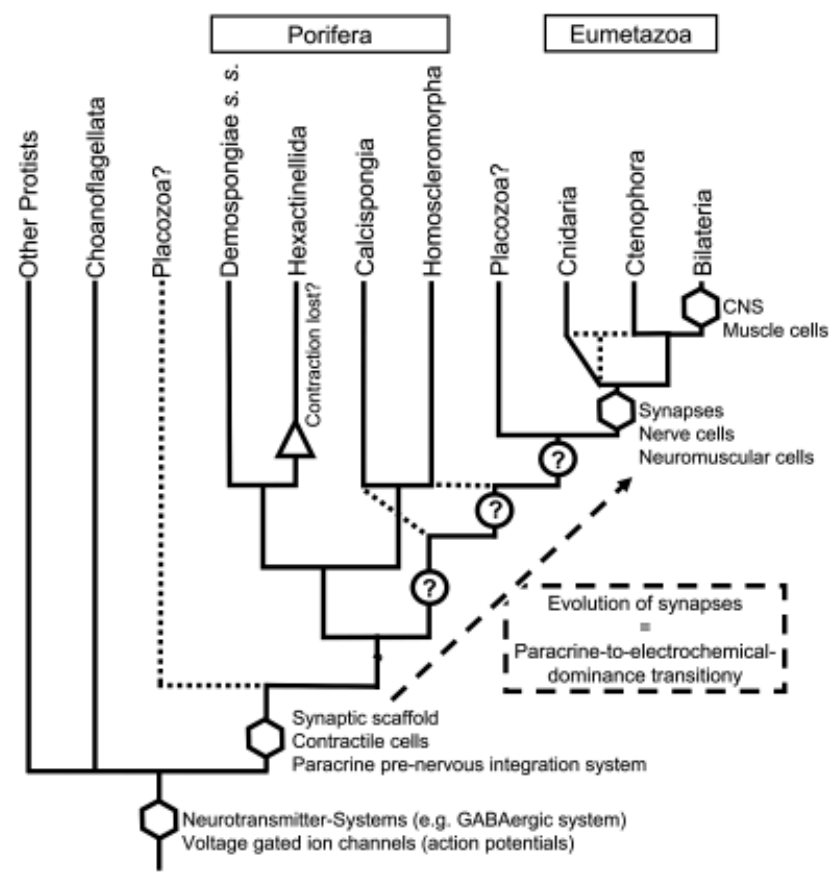

Fig. 5. Summary of the co-evolution of integration and effector systems in Metazoa. The phylogenetic tree follows Borchiellini et al. (2001), Schmidt-Rhaesa (2007), Philippe et al. (2009), and others, with alternative scenarios presented as dashed lines. The position of Placozoa remains a matter of debate (Philippe et al. 2009; Schierwater et al. 2009), but will be of special interest for our understanding as soon as more details on the placozoan integration system are known. The evolution of the ultrastructure of synapses remains unresolved, but the synapse gene repertoire seems to be plesiomorphic to all Metazoa. CNS, central nervous system; GABA, $\gamma$-amino butyric acid.

still known about these systems than other integrative systems such as the nerve nets of cnidarians.

The phylogenetic relationships between all the basal branching metazoan groups need to be clarified (Fig. 5). The phylogenetic position of the Placozoa will be of special interest (e.g., Collins et al. 2005; Schierwater \& DeSalle 2007), as will be the question of the para- or the monophyly of sponges (e.g., compare Borchiellini et al. 2001; Philippe et al. 2009). It has been postulated that Ctenophora might represent the most basal branching metazoan clade (Dunn et al. 2008); support for this hypothesis is weak. However, it is worth considering in the context of nervous system evolution. Because ctenophorans possess synapses and nerve cells arranged in nerve nets (Bullock \& Horridge 1969; Hernandez-Nicaise 1973; Schmidt-Rhaesa 2007), the consequence would be that the synaptic nervous system either evolved independently or that synapses evolved in early stem groups of the Metazoa (Miller 2009). In the latter case, the synapseless and nerveless condition in the Porifera and the Placozoa would be secondary. This scenario seems to be less parsimonious than others that consider the Porifera and the Placozoa to represent the basal branches of the metazoan tree (Fig. 5).

It has recently been stated that the genomics of basal metazoans will be of particular importance in understanding the origin of complex metazoan systems such as the nervous system (Kosik 2009). I think an integrative approach that uses genomic evidence as a primer for key experiments will bring us even further. We will need to pursue both expression studies and immunohistochemical studies in adult sponges to demonstrate the distribution of synaptic proteins among sponge cell types, as well as on the sub-cellular level. Further physiological experiments will be needed to clarify the specificity of paracrine signaling. Such an experimental approach will include assays applying combinations of agonists and specific antagonists, and require advanced life cell imaging techniques such as intracellular calcium imaging. Refined and miniaturized cultivation systems for sponge cells, tissue, and whole juvenile sponges will be needed for such experiments. The question of action potentials in Demospongiae, Homoscleromorpha, and Calcispongia will also have to be addressed experimentally. New reverse genetics techniques, such as RNA interference and transgenic manipulation, will have to be established, and refined reproduction and breeding protocols will have to be developed in order to secure sponges a place among the relevant model organisms.

Acknowledgments. I would like to thank Sally P. Leys (Edmonton, Canada), Dennis V. Lavrov (Ames, USA), Calhoun Bond (Greensboro, USA), Roberto Pronzato (Genova, Italy), Alexander Ereskovsky (St. Petersburg, Russia), Carole Borchiellini and Jean Vacelet (both Marseille, France), Jörg U. Hammel and Christopher Arnold (both Jena, Germany), and George O. Mackie and Henry Reiswig (both Victoria, Canada) for material, discussions, and comments, and Rudi Loesel (Aachen, Germany), Andreas Wanninger (Copenhagen, Denmark), and Steffen Harzsch (Greifswald, Germany) for organizing the ICIM 1 symposium on neurophylogeny. Christopher Arnold performed additional experiments and provided unpublished data. Felix Beckmann (Hamburg, Germany) enabled us to perform microtomographic scans. Greg Rouse (La Jolla, USA), Robert Meech (Bristol, UK), and two anonymous reviewers provided constructive input that helped to improve the article, which is greatly appreciated. I am grateful to Martin S. Fischer (Jena, Germany) for supporting my work and providing infrastructure. 
Katherine Zocholl (Ulm, Germany) and Lucy Cathrow (Rostock, Germany) improved the language of this article. This article is in memoriam Max Pavans de Cecatty (19272009), who greatly inspired my research and influenced many biologists and their views on sponges.

\section{References}

Anderson PA 1985. Physiology of a bidirectional, excitatory, chemical synapse. J. Neurophysiol. 53: 821-835.

Arndt W 1941. Lebendbeobachtungen an Kiesel- und Hornschwämmen des Berliner Aquariums. Zool. Gart. (Leipzig) 13: 140-166.

Bacq ZM 1947. L'acétylcholine et l'adrénaline chez lez Invertébrés. Biol. Rev. 22: 73-91.

Bagby RM 1966. The fine structure of myocytes in the sponges Microciona prolifera (Ellis and Sollander) and Tedania ignis (Duchassaing and Michelotti). J. Morphol. 118: $167-182$.

1970. The fine structure of pinacocytes in the marine sponge Microciona prolifera. Z. Zellforsch.Mikrosk. Anat. 105: 579-594.

Barbara J-G 2006. The physiological construction of the neurone concept (1891-1952). C. R. Biol. 329: 437449.

Bidder GP 1937. The perfection of sponges. Proc. Linn. Soc. London 149: 119-147.

Bond C 1992. Continuous cell movements rearrange anatomical structures in intact sponges. J. Exp. Zool. 263: 284-302.

Borchiellini C, Manuel M, Alivon E, Boury-Esnault N, Vacelet J, \& Le PY 2001. Sponge paraphyly and the origin of Metazoa. J. Evol. Biol. 14: 171-179.

Boury-Esnault N \& Rützler K 1997. Thesaurus of sponge morphology. Smithson. Contrib. Zool. 596: 1-55.

Bullock TH \& Horridge G 1969. Structure and Function of the Nervous Systems of Invertebrates. W.H. Freeman, San Fransisco.

Colasanti M \& Venturini G 1998. Nitric oxide in invertebrates. Mol. Neurobiol. 17: 157-174.

Collins AG, Cartwright P, McFadden CS, \& Schierwater B 2005. Phylogenetic context and basal metazoan model systems. Integr. Comp. Biol. 45: 585-594.

Dunn CW, Hejnol A, Matus DQ, Pang K, Browne WE, Smith SA, Seaver E, Rouse GW, Obst M, Edgecombe GD, Sorensen MV, Haddock SHD, Schmidt-Rhaesa A, Okusu A, Kristensen RM, Wheeler WC, Martindale MQ, \& Giribet G 2008. Broad phylogenomic sampling improves resolution of the animal tree of life. Nature 452: 745-749.

Elliott GRD \& Leys SP 2007. Coordinated contractions effectively expel water from the aquiferous system of a freshwater sponge. J. Exp. Biol. 210: 3736-3748.

Ellwanger K \& Nickel M 2006. Neuroactive substances specifically modulate rhythmic body contractions in the nerveless metazoon Tethya wilhelma (Demospongiae, Porifera). Front. Zool. 3: 7.
Ellwanger K, Eich A, \& Nickel M 2007. GABA and glutamate specifically induce contractions in the sponge Tethya wilhelma. J. Comp. Physiol. A Sensory Neural Behav. Physiol. 193: 1-11.

Emson RH 1966. The reactions of the sponge Cliona celata to applied stimuli. Comp. Biochem. Physiol. 18: 805-827.

Fredholm BB, Arslan G, Halldner L, Kull B, Schulte G, \& Wasserman W 2000. Structure and function of adenosine receptors and their genes. Naunyn-Schmiedebergs Arch. Pharmacol. 362: 364-374.

Grundfest H 1959. Evolution of conduction in the nervous system. In: Evolution of Nervous Control from Primitive Organisms to Man. Bass A, ed., pp. 43-86. American Association for the Advancement of Science, Washington.

1965. Evolution of electrophysiological varieties among sensory receptor systems. In: Essays on Physiological Evolution. Pringle J, ed., pp. 107-138. The Macmillan Company, New York.

Hanström B 1928. Vergleichende Anatomie des Nervensystems der wirbellosen Tiere unter Berücksichtigung seiner Funktion. Springer, Berlin.

Hernandez-Nicaise M-L 1973. The nervous system of ctenophores III. Ultrastructure of synapses. J. Neurocytol. 2: 249-263.

Hertwig O \& Hertwig R 1878. Das Nervensystem und die Sinnesorgane der Medusen. Vogel, Leipzig.

Horridge G 1968. Interneurons: Their Origin, Action, Specificity, Growth, and Plasticity. W.H. Freeman, London.

Hoyer D, Clarke DE, Fozard JR, Hartig PR, Martin GR, Mylecharane EJ, Saxena PR, \& Humphrey PP 1994. International Union of Pharmacology classification of receptors for 5-hydroxytryptamine (serotonin). Pharmacol. Rev. 46: 157-203.

Jacklet JW 1997. Nitric oxide signalling in invertebrates. Invert. Neurosci. 3: 1-14.

Jacobs DK, Nakanishi N, Yuan D, Camara A, Nichols SA, \& Hartenstein V 2007. Evolution of sensory structures in basal metazoa. Integr. Comp. Biol. 47: 712-723.

Jones WC 1957. The contractility and healing behaviour of pieces of Leucosolenia complicata. Q. J. Microsc. Sci. 98: 203-217.

1962. Is there a nervous system in sponges? Biol. Rev. 37: 1-50.

Kosik KS 2009. Exploring the early origins of the synapse by comparative genomics. Biol. Lett. 5: 108-111.

Lentz TL 1966. Histochemical localization of neurohumors in a sponge. J. Exp. Zool. 162: 171-180.

1968. Primitive Nervous Systems. Yale University Press, New Haven. 148 pp.

Leys SP 2007. Sponge coordination, tissues, and the evolution of gastrulation. In: Porifera Reserach: Biodiversity, Innovation and Sustainability. Custódio M, Lôbo-Hajdu G, Hajdu E, \& Muricy G, eds., pp. 53-59. Série Livros 28. Museu Nacional, Rio de Janeiro.

Leys SP \& Degnan BM 2001. Cytological basis of photoresponsive behavior in a sponge larva. Biol. Bull. 201: 323-338. 
Leys SP \& Mackie GO 1997. Electrical recording from a glass sponge. Nature 387: 29-30.

1999. Propagated electrical impulses in a sponge. Mem. Queensl. Mus. 4430: 342.

Leys SP \& Meech RW 2006. Physiology of coordination in sponges. Can. J. Zool. 84: 288-306.

Leys SP, Mackie GO, \& Meech RW 1999. Impulse conduction in a sponge. J. Exp. Biol. 202: 1139-1150.

Leys SP, Mackie GO, Reiswig HM, \& David WS 2007. The Biology of Glass Sponges. Academic Press. 145 pp.

Leys SP, Nichols SA, \& Adams EDM 2009. Epithelia and integration in sponges. Integr. Comp. Biol. (in press).

Lichtneckert R \& Reichert H 2007. 1.19 Origin and Evolution of the First Nervous System. In: Evolution of Nervous Systems. Volume 1: Theories, Development, Invertebrates. Kaas JH, ed., pp. 289-315. Academic Press, Amsterdam, the Netherlands.

Loewenstein WR 1967. On the genesis of cellular communication. Dev. Biol. 15: 503-520.

Mackie GO 1970. Neuroid conduction and the evolution of conducting tissue. Q. Rev. Biol. 45: 319-332.

1979. Is there a conduction system in sponges? In: Biologie des Spongiaires. Editions du C.N.R.S. Lévi C \& Boury-Esnault N, eds., pp. 145-152. C.N.R.S., Paris. 1990. The elementary nervous system revisited. Am. Zool. 30: 907-920.

Marshall W 1885. Coelenterata, Porifera, Tetractinellidae. In: Zoologische Wandttafeln der wirbellosen Thiere. Leuckart R, ed., Tafel XLVII. Th. Fischer, Kassel.

Martindale MQ, Pang K, \& Finnerty JR 2004. Investigating the origins of triploblasty: "mesodermal" gene expression in a diploblastic animal, the sea anemone Nematostella vectensis (phylum, Cnidaria; class, Anthozoa). Development 131: 2463-2474.

Matsuno A, Ishida H, Kuroda M, \& Masuda Y 1988. Ultrastructures of contractile bundles in epithelial cells of the sponge. Zool. Sci. 5: 1212.

Mattson MP \& Bruce-Keller AJ 1999. Compartmentalization of signaling in neurons: evolution and deployment. J. Neurosci. Res. 58: 2-9.

Meech RW 2008. Non-neural reflexes: sponges and the origins of behaviour. Curr. Biol. 18: R70-R72.

Meech RW \& Mackie GO 2007. Evolution of excitability in lower metazoans. In: Invertebrate Neurobiology. North G \& Greenspann J, eds., pp. 581-615. Cold Spring Harbor Laboratory Press, New York.

Miller G 2009. On the origin of the nervous system. Science 325: 24-26.

Minchin E 1900. Sponges. In: A Treatise on Zoology. Part II The Porifera and Coelentera. Lancester ER, ed., pp. 1-178. Adam \& Charles Black, London.

Mitropolitanskaya R 1941. On the presence of acetylcholin and cholinesterases in the Protozoa, Spongia and Coelenterata. C. R. Dokl. Acad. Sci. Union Sov. Soc. Republ. 31: 717-718.

Nguyen L, Rigo J-M, Rocher V, Belachew S, Malgrange B, Rogister B, Leprince P, \& Moonen G 2001. Neurotransmitters as early signals for central nervous system development. Cell Tissue Res. 305: 187-202.
Nichols SA, Dirks W, Pearse JS, \& King N 2006. Early evolution of animal cell signaling and adhesion genes. Proc. Nat. Acad. Sci. USA 103: 12451-12456.

Nickel M 2001. Cell biology and biotechnology of marine invertebrates. Sponges (Porifera) as model organisms. Dissertation, Universität Stuttgart, Stuttgart. 157 pp.

2004. Kinetics and rhythm of body contractions in the sponge Tethya wilhelma (Porifera: Demospongiae). J. Exp. Biol. 207: 4515-4524.

2006a. Biomechanik und Physiologie der Bewegung nerven- und muskelloser Metazoa, am Beispiel von Tethya wilhelma (Porifera). Universität Stuttgart, Habilitationsschrift. $361 \mathrm{pp}$.

2006b. Like a 'rolling stone': quantitative analysis of the body movement and skeletal dynamics of the sponge Tethya wilhelma. J. Exp. Biol. 209: 28392846.

Nickel M \& Brümmer F 2004. Body extension types of Tethya wilhelma: cellular organisation and their function in movement. Boll. mus. ist. biol. Univ. Genova 68: 483489.

Nickel M, Bullinger E, \& Beckmann F 2006a. Functional morphology of Tethya species (Porifera): 2. Threedimensional morphometrics on spicules and skeleton superstructures of $T$. minuta. Zoomorphology 125 : 225-239.

Nickel M, Donath T, Schweikert M, \& Beckmann F 2006b. Functional morphology of Tethya species (Porifera): 1. quantitative $3 \mathrm{D}$-analysis of $T$. wilhelma by synchrotron radiation based $\mathrm{x}$-ray microtomography. Zoomorphology 209-223.

Nickel M, Hammel J, Donath T, \& Beckmann F 2006c. Elastic energy load into spicule reinforced extracellular matrix of the sponge Tethya wilhelma? - evidence from synchrotron radiation based x-ray microtomography. In HASYLAB Annual Report 2006. Part I. Krell U, Schneider J, \& von Zimmermann M, eds., pp 1279-1280. DESY, Hamburg. Available at http://hasyweb.desy.de/ science/annual_reports/2006_report/part1/contrib/47/ 17965.pdf.

Nickel M, Hammel J, Herzen J, Bullinger E, \& Beckmann F 2008. High density resolution synchrotron radiation based x-ray microtomography (SR $\mu \mathrm{CT}$ ) for quantitative 3D-morphometrics in zoological sciences. Proc. SPIE $70781 \mathrm{~W}, 1-11$.

Oberdisse E, Hackenthal E, \& Kuschinsky K 1997. Pharmakologie und Toxikologie. Springer-Verlag, Heidelberg. $770 \mathrm{pp}$.

Pantin CFA 1952. The elementory nervous system. Proc. Roy. Soc. Lond. Ser. B Biol. Sci. 140: 147-168.

1956. The origin of the nervous system. Pubbl. Staz. Zool. Napoli 28: 171-181.

Parker GH 1910. The reactions of sponges, with a consideration of the origin of the nervous system. J. Exp. Zool. 8: 765-805.

1919. The Elementary Nervous System. Lippincott, Philadelphia. 229 pp.

Passano L 1963. Primitive nervous systems. Proc. Nat. Acad. Sci. USA 50: 306-313. 
Pavans de Ceccatty M 1959. Les structures cellulaires de type nerveux chez Hippospongia communis LMK. Ann. Sci. Nat. Zool. Biol. Anim. 12: 105-112.

1960. Les structures cellulaires de type nerveux et de type musculaire de l'éponge siliceuse Tethya lyncurium Lmck. C. R. Acad. Sci. Paris 251: 1818-1819.

1971. Effects of drugs and ions on a primitive system of spontaneous contractions in a sponge (Euspongia officinalis). Experientia 27: 57-59.

1974. Coordination in sponges the foundations of integration. Am. Zool. 14: 895-903.

1979. Cell correlations and integrations in sponges. In: Biologie des Spongiaires. Lévi C \& Boury-Esnault N, eds., pp. 123-135. Editions du CNRS, Paris.

1981. Demonstration of actin filaments in sponge cells. Cell Biol. Int. 5: 945-952.

1986. Cytoskeletal organization and tissue patterns of epithelia in the sponge Ephydatia mülleri. J. Morphol. 189: 45-66.

1989. Les éponges, à l'aube des communications cellulaires. Pour la Sci. 142: 64-72.

Perovic S, Krasko A, Prokic I, Mueller IM, \& Mueller WEG 1999. Origin of neuronal-like receptors in Metazoa: cloning of a metabotropic glutamate/GABA-like receptor from the marine sponge Geodia cydonium. Cell Tissue Res. 296: 395-404.

Philippe H, Derelle R, Lopez P, Pick K, Borchiellini C, Boury-Esnault N, Vacelet J, Renard E, Houiliston E, Quéinnec E, Da Silva C, Wincker P, Le Guyader H, Leys S, Jackson DJ, Schreiber F, Erpenbeck D, Morgenstern B, Wörheide G, \& Manuel M 2009. Phylogenomics revives traditional views on deep animal relationships. Curr. Biol. 19: 1-7.

Pierobon P, Minei R, Porcu P, Sogliano C, Tino A, Marino G, Biggio G, \& Concas A 2001. Putative glycine receptors in Hydra: a biochemical and behavioural study. Eur. J. Neurosci. 14: 1659-1666.

Prosser CL, Nagai T, \& Nystrom RA 1962. Oscular contraction in sponges. Comp. Biochem. Physiol. 6: 69-74.

Ramoino P, Fronte P, Beltrame F, Diasporo A, Fato M, Raiteri L, Stigliani S, \& Usai C 2003. Swimming behaviour regulation by $\mathrm{GABA}_{\mathrm{B}}$ receptors in Paramecium. Exp. Cell Res. 291: 398-405.

Ramoino P, Scaglione S, Diasporo A, Beltrame F, Fato M, \& Usai C 2004. GABA $_{\mathrm{A}}$ receptor subunits identified in Paramecium by immunofluorescence confocal microscopy. FEMS Microbiol. Lett. 238: 449-453.

Ramoino P, Usai C, Beltrame F, Fato M, Gallus L, Tagliafierro G, Magrassi R, \& Diaspro A 2005. GABA receptor intracellular trafficking after internalization in Paramecium. Microsc. Res. Tech. 68: 290-295.

Ramoino P, Gallus L, Paluzzi S, Raiteri L, Diaspro A, Fato M, Bonanno G, Tagliafierro G, Ferretti C, \& Manconi R 2007. The GABAergic-like system in the marine demosponge Chondrilla nucula. Microsc. Res. Tech. 70: 944-951.

Ramon y Cajal S 1937. Recollections of my life. Mem. Am. Phil. Soc. 8: 1-638.
Renard E, Vacelet J, Gazave E, Lapébie P, Borchiellini C, \& Ereskovsky AV 2009. Origin of the neuro-sensory system: new and expected insights from sponges. Integr. Zool. 4: 294-308.

Richards GS, Simionato E, Perron M, Adamska M, Vervoort M, \& Degnan BM 2008. Sponge genes provide new insight into the evolutionary origin of the neurogenic circuit. Curr. Biol. 18, 1156-1161.

Ruediger T \& Bolz J 2007. Neurotransmitters and the development of neuronal circuits. In: Axon Growth and Guidance. Bagnard D, ed., pp. 104-115. Series: Advances in Experimental Medicine and Biology Volume 621. Landes Bioscience and Springer Science+Business Media, TX, USA.

Sakarya O, Armstrong KA, Adamska M, Adamski M, Wang IF, Tidor B, Degnan BM, Oakley TH, \& Kosik KS 2007. A Post-synaptic scaffold at the origin of the animal kingdom. PLoS One 2: e506.

Satir P \& Christensen ST 2007. Overview of structure and function of mammalian cilia. Ann. Rev. Physiol. 69: 377-400.

Schierwater B \& DeSalle R 2007. Can we ever identify the Urmetazoan? Integr. Comp. Biol., 670-676.

Schierwater B, Eitel M, Jakob W, Osigus H-J, Hadrys H, Dellaporta SL, Kolokotronis S-O, \& DeSalle R 2009. Concatenated analysis sheds light on early metazoan evolution and fuels a modern "Urmetazoon" hypothesis. PLoS Biol. 7: e1000020.

Schmidt O 1866. Zweites Supplement der Spongien des Adriatischen Meeres enthaltend die Vergleichung der Adriatischen und Britischen Spongiengattungen. Verlag von Wilhelm Engelmann, Leipzig. 23 pp.

Schmidt-Rhaesa A 2007. The Evolution of Organ Systems. Oxford University Press, Oxford.

Seipel K \& Schmid V 2006. Mesodermal anatomies in cnidarian polyps and medusae. Int. J. Dev. Biol. 50: 589-599.

Sherrington CS 1897. Croonian lecture: The mammalian spinal cord as an organ of reflex action. Proc. Roy. Soc. Lond. 61: 220-221.

Shibata S 2004. Neural regulation of the hepatic circadian rhythm. Anat. Rec. Part A Discov. Mol. Cell. Evol. Biol. 280A: 901-909.

Simpson TL 1984. The Cell Biology of Sponges. Springer Verlag, New York. 662 pp.

Sollas WJ 1888. Report on the Tetractinellida collected by H.M.S. Challenger during the years 1873-1876. Report on the scientific results of the voyage of H.M.S. Challenger 25: 1-458.

Spring J, Yanze N, Jösch C, Middel AM, Winninger B, \& Schmid V 2002. Conservation of brachyury, Mef2, and snail in the Myogenic lineage of jellyfish: a connection to the mesoderm of bilateria. Dev. Biol. 244: 372 384.

Steinmetz PRH, Saina M, Amon-Hassenzahl A, Houliston E, Degnan B, \& Technau U 2008. An early metazoan origin of striated and smooth muscle cell types. ICREA Conference on the Origin and Early Evolution of Metazoans, October 24-25, 2008, Barcelona, Programme: 8. 
Thiney Y 1972. Morphologie et cytochimie ultrastructurale de l'oscule d'Hippospongia communis LMK et de sa régénération. $\mathrm{PhD}$ thesis, Université Claude Bernard (Lyon I). pp. 1-63.

Tompkins-MacDonald GJ, Gallin WJ, Sakarya O, Degnan B, Leys SP, \& Boland LM 2009. Expression of a poriferan potassium channel: insights into the evolution of ion channels in metazoans. J. Exp. Biol. 212: 761767.

Vacelet J 1966. Les cellules contractiles de l'éponge cornée Verongia cavernicola Vacelet. C. R. Acad. Sci. Paris 263: 1330-1332.

Walker RJ \& Holden-Dye L 1991. Evolutionary aspects of transmitter molecules, their receptors and channels. Parasitology 102: S7-S29.

Walker RJ, Brooks HL, \& Holden-Dye L 1996. Evolution and overview of classical transmitter molecules and their receptors. Parasitology 113: S3-S33.

Weissenfels N 1984. Bau und Funktion des Süßwasserschwammes Ephydatia fluviatilis L. (Porifera). XI. Nachweis einer endogenen Kontraktionsrhythmik durch Infrarot-Reflexion. Zoomorphology 104: 292-297.

1989. Biologie und Mikroskopische Anatomie der Süßwasserschwämme (Spongillidae). Gustav Fischer Verlag, Stuttgart. 110 pp.

Weyrer S, Rützler K, \& Rieger R 1999. Serotonin in Porifera? Evidence from developing Tedania ignis, the Caribbean fire sponge (Demospongiae). Mem. Queensl. Mus. 44: 659-665.

Wilson HV 1910. A study of some epitheloid membranes in monaxonid sponges. J. Exp. Zool. 9: 536-571.
Zocchi E, Carpaneto A, Cerrano C, Bavestrello G, Giovine M, Bruzzone S, Guida L, Franco L, \& Usai C 2001. The temperature-signaling cascade in sponges involves a heat-gated cation channel, abscisic acid, and cyclic ADP-ribose. Proc. Nat. Acad. Sci. USA 98: 1485914864.

\section{Supporting information}

Additional supporting information may be found in the online version of this article:

Text S1. Axioms for an extended hypothesis, including new concepts from recent evidence.

Movie S1. Example for contraction in Demospongiae: A series of regular contraction of Tethya wilhelma. Time lapse movie taken in an aquarium. For method details see Ellwanger \& Nickel (2006).

Movie S2. Example for contraction in Homoscleromorpha: Contractile waves running over the body of Oscarella sp. Time lapse movie taken in an aquarium. For method details see Ellwanger \& Nickel (2006).

Movie S3. Example for contraction in Calcarea: A slow contraction-expansion cycle in Clathrina clathrus. Time lapse movie taken in an aquarium. For method details see Ellwanger \& Nickel (2006).

Please note: Wiley-Blackwell is not responsible for the content or functionality of any supporting materials supplied by the authors. Any queries (other than missing material) should be directed to the corresponding author for the article. 